\title{
Dr. Brana János (1881-1949) orvos-tábornok, szemész szakorvos, egyetemi tanár Történelmi fordulópontok és jeles események egy magyar katonaorvos életében
}

\author{
Pogányné Dr. Rózsa Gabriella PhD \\ Kulcsszavak: Dr. Brana János - életrajz - Honvédorvos 1929-1936 \\ - katonaorvos-tudomány története
}

\begin{abstract}
Brana János (1881-1949) erdélyi származású szemész szakorvos, orvos tábornok, a Magyar Királyi Pázmány Péter Tudományegyetem egyetemi tanára élete nyomon követi a XX. századi magyar történelem fordulóit. Katonaorvosa volt az Osztrák-Magyar Monarchia császári és királyi közös hadseregének, a Monarchia szétesése után a Magyar Királyi Honvédségnek. Tudományos munkássága az egyetem mellett 1929 és 1936 között a Honvédorvos szerkesztőségéhez kötötte, tagja volt a Honvédorvosok Tudományos Egyesületének és aktív ágense volt a korabeli orvosi szakmai közéletnek.
\end{abstract}

2019-ben emlékezhet a magyar katonaorvos-társadalom Dr. Brana János orvos tábornok, szemész szakorvos, egyetemi tanár halálának 70. évfordulójára. Brana doktor neve mára már jócskán a feledés homályába merült annak ellenére, hogy korának katonai és katonaorvosi szakmai szempontból is megbecsült, tiszteletre méltó, a napilapok cikkei nyomán pedig a közvélemény számára szintén jól ismert, jó hírnevü személyisége volt. A mai Honvédkórház pedig régi kollégáját tisztelheti benne.

Brana János 1881. január 22-én született az erdélyi Hevesmezőn (Ruszpoljána), Máramaros megyében, apja a helyi nép-

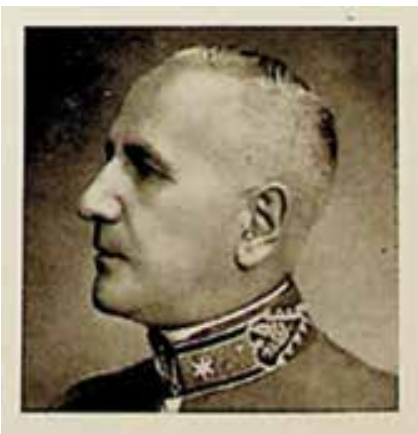

Dr. Brana János [1]

iskola igazgatója volt, akinek korai halála után neveltetését nagybátyja, id. Brana János rutén görög katolikus esperes vállalta magára. 1900-ban tett érettségit 
az ungvári katolikus főgimnáziumban, majd a kassai jogakadémián kezdte meg tanulmányait, közben azonban a császári és királyi közös hadsereg katonaorvosi ösztöndíját elnyerve 1900. október végétől orvosi stúdiumokat folytatott a budapesti Királyi Magyar Tudományegyetemen [2]. 1905-ben szerzett doktori címet, december 1-jétől pedig a bécsi katonaorvosi alkalmazóiskola hallgatója lett. 1906 őszétől majdnem egy éven át a budai 17. számú helyőrségi kórház főorvosaként szolgált, innen került a császári és királyi 12. ulánusezredhez Tolnára. 1908-ban ezredorvosi rangba helyezték, ezutáni első állomáshelye Szeged lett [3]; itt kötött házasságot Kass Ilonával [4], aki abból a szegedi szállodatulajdonos Kass-családból származik, amely később a híres grafikus Kass Jánost adta a magyar művészetnek. 1912-ig Székesfehérvárott, Pancsovában majd Kolozsvárott szolgált, utóbbi városban egy éven át a szemklinikán „speciális szemészkiképzésben" részesült. Innen került a przemysli 3. számú helyőrségi kórház szemészeti osztályára és itt gyógyított a Nagy Háború kezdetéig. A mozgósításkor a közös hadsereg 45-ös gyalogezredének orvosfönökévé nevezték ki, ebben a minőségében került orosz hadifogságba 1914. november 10-én egészségügyi személyzetével és három orvostársával együtt. Hároméves raboskodása első időszakát Nyizsnij Novgorod „öreg fogház"-ában töltötte, ahol tiszttársaival együtt tiszti étkezőt létesített [5] - ez azonban a XX. század első évtizedeiben már nem csupán a testi táplálék felvételének helyszíne volt a laktanyák, garnizonok életében, hanem a tisztek szellemi találkozóhelyei, így a kantinok a rendelkezésre álló anyagi források és egyéb lehetőségek függvényében a tudományos és kaszinóegyletek székhelyei is voltak. A hadifogságban tehát az étkezde megszervezése a helyőrségi „normális” tiszti létre és életformára való törekvés eredménye [6]. Brana doktor korábban éppígy volt aktív részese a katonai/katonaorvosi tudományos életnek, a közös hadsereg Militärarzt címü katonaorvosi folyóirata is beszámolt arról, hogy a przemysli katonai kórházban 1913. december 1-jén előadást tartott a helyőrségi katonaorvosok tudományos egyletében (Wissenschaftlicher Verein der Militärärzte der Garnison Przemysl) [7]

Hadifogsága második évében Hermann Kusmanek gyalogsági tábornoknak, Przemysl védőjének "háziorvosa” lett, kit vezérkarával együtt internáltak, így szintén Nyizsnij Novgorodban raboskodott. Az utolsó fogoly-évét azonban újra a táborban töltötte, ahol különféle fertőző betegségekben szenvedő fogolytársait kellett gyógyítania, közben maga is megbetegedett és a moszkvai katonai kórházba került rabnak, betegnek, szemész szakorvosnak egy személyben. Fogsága élményeit és orvosi ténykedésének legfontosabb momentumait később tudományos dolgozat formájában tette közkinccsé a Magyar Katonai Szemle hasábjain Orvosi megfigyelések és tapasztalatok orosz hadifogságban [8] címen. A közlemény az orvosi szakmai szempontok, a leggyakoribb betegségek (kiütéses tífusz, tuberkulózis és egyéb fertőzések, fagyási sérülések) mellett részletesen ismertette a lelki terhek miatti pszichés zavarokat és a foglyok, a legénység, valamint a tisztek ellátásának nehézségeit, de éppígy felelevenítette a hadifogság éveinek eseményeit, a táborélet mindennapjait.

A napisajtóban már 1916 júliusában híre kelt, hogy kiszabadul fogságából $\left[{ }^{9}\right]$, ám végül csak 1917 februárjában jutott Pétervárra egy invalidus-transzporttal, 


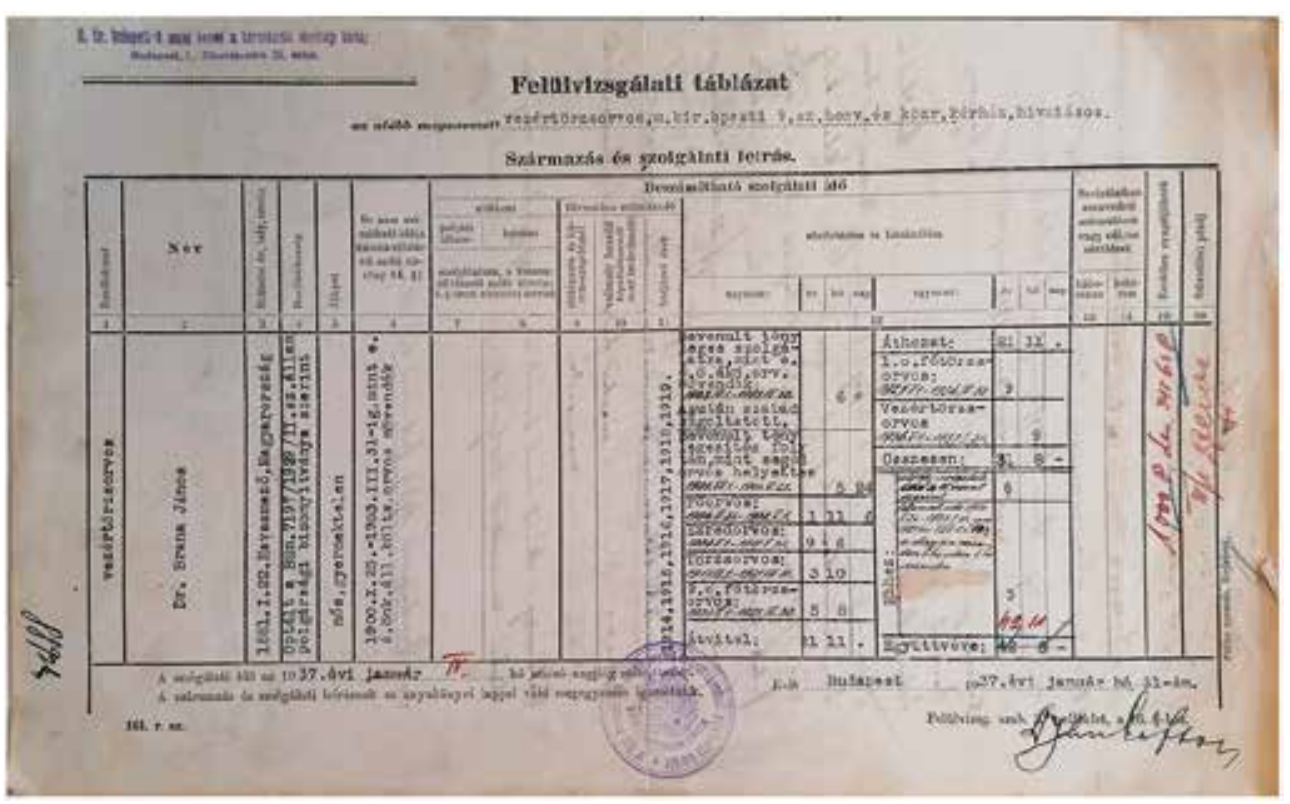

Dr. Brana János felülvizsgálati táblázata [13]

onnan pedig a Finn-öböl mellett egy katonai kórházba és itt élte át a forradalmat is. 1917 nyarán indulhatott haza. Itthon a nagyváradi, később a zágrábi helyőrségi kórház szemészeti osztályának lett vezetőorvosa ekkor már törzsorvosi rangban. Az 1918-as és 1919-es magyar forradalmak alatt eleinte Zágrábban tartózkodott, majd Szegeden volt felesége szüleinél. Világnézeti okok miatt nyugdíjazását kérte és a szegedi Kerületi Katonai Parancsnokság 7903/56. sz. rendeletével 1919. március 1-jével helyezte nyugállományba. A kommün bukása után nyugdíjazási kérelmét visszavonta és 1919. szeptember 1-jétől Budapesten szolgált a mai Honvédkórházban, akkori nevén a „volt 16. számú helyőrségi kórház"-ban [10], illetve annak jogutódjában a 2. számú Helyőrségi Kórházban a szemészeti osztály doktoraként, 1920-tól osztályvezetőjeként. „A trianoni békeszerződés folytán”, vagyis a dokumentumban elöírt haderőcsökkentés következtében 1921-ben nyugállományba helyezték, utóbb azonban visszatért a katonaorvosi szolgálatba. A Róbert Károly körúti kórházból 1928. november 1-jével a budai, 3. számú Honvéd és Közrendészeti Kórház igazgatójává nevezte ki a kormányzó „főtanácsnok orvos"-ként, 1929. szeptember 1-jével kapott újra katonaorvosi rangot, ekkor sorolták be I. osztályú fötörzsorvosnak. 1935. május 1-jével ugyanitt kórházparancsnoki megbízást kapott [11], de ugyanekkor a HM 102476/eln. 12. - 1935. számú rendeletével az 1. vegyesdandár parancsnoksághoz helyeztetett vezetőorvosnak. Brana vezértörzsorvos 1936-ban újra a budai honvéd kórház állományában van mint a Honvéd és Közrendészeti Egészségügyi Tanács elnöke. Horthy kormányzó 1937. március 3-ai dátummal rendelte el nyugállományba helyezését [12].

A Magyar Királyi Honvédség kötelékéből való kiválás azonban - látható lesz - nem jelentette Brana János doktor életében az orvoslásból és a tudományos munkából való kilépést is. 
Katonaorvosi karrierje során több elismerésben részesült: a Magyar Érdemrend Középkeresztje, a Magyar Tiszti Érdemkereszt, a Magyar Signum Laudis, ennek szalagján a Ferenc József-rend lovagkeresztje kardokkal, a Háborús Signum Laudis a kardokkal, a Károlycsapatkereszt, a Magyar Háborús Emlékérem, az osztrák háborús emlékérem kardokkal elnevezésü érdemrendek tulajdonosa [14], a Magyar Érdemrend Tiszti Keresztjét 1930-ban és 1937-ben [15] nyerte el. A Magyar Katonai Szemle arról is tudósított, hogy 1933-ban Brana János dr. I. osztályú fötörzsorvosnak, a budapesti 9. számú (ez a korábban 3. számú gyógyintézménnyel azonos) helyőrségi kórház parancsnokának és egyetemi magántanárnak pápai kitüntetésként „[XI. Piusz] pápa Öszentsége sajátkezű aláírásával ellátott fényképét küldte” meg, melyet „Luttor Ferenc pápai prelátus [adott] át a honvédkórházban egybegyült közönség és a kórház tisztikara előtt" [16]. Brana János orvos tábornok, egyetemi tanár 1942-ben már a vitézi cím birtokosaként (vitéz Bogdánfy Brana János) Nemzetvédelmi Keresztet kapott [17].

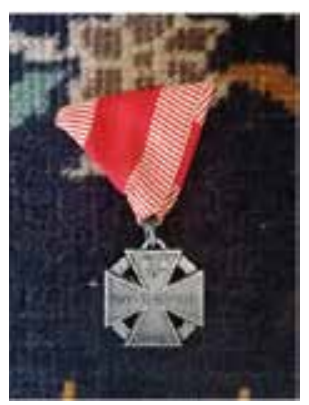

Károly csapatkereszt [18]

Dr. Brana János tudományos müködését még przemysli időszakában kezdte meg, számos tanulmánya, előadásának összefoglalója olvasható a Gyógyászat- ban, az Orvosi Hetilapban, a Budapesti Orvosi Újságban, az Orvosképzésben és természetesen a Honvédorvosban is. 1924 júniusától tagja a Budapesti Királyi Orvosegyesületnek [19], 1928-ban egyetemi magántanári címet szerzett a Budapesti Királyi Magyar Pázmány Péter Tudományegyetem Orvostudományi Karán, a kari tanács - meglehetősen akadozó, már 1936-ban megkezdett elökészítő folyamat után - 1937. december 14-ei ülésén pedig a rendkívüli tanári címet is odaítélte neki.

Az eljárás során Brana szakirodalmi munkásságát Dr. Blaskovits László, Dr. Lénárt Zoltán és Dr. Kelen Béla egyetemi tanárok értékelték. Publikációinak elemzéséből megállapították [20], hogy szakírói müködésének egyik tartalmi csomópontja, „kedvenc témája a trachoma etiológiája”. A Honvédorvosban is jelent meg cikke e témában A trachoma elleni küzdelem Magyarországon címmel, amelyben a betegség leküzdésére irányuló intézkedéseket vázolta, kitérve a törvényi szabályozásra, a szemkórházi intézményrendszer fejlesztésére és a népegészségügy releváns általános kérdései figyelembevételének fontosságára is [21]. E probléma azonban akkoriban nemzetközi színtéren is foglalkoztatta a szemorvosokat, az 1929 szeptemberében Amszterdamban megtartott XIII. nemzetközi szemészeti kongresszus két fö témája a glaukóma és a trachoma volt. „Mi magyarok méltán büszkék lehetünk arra, hogy a legrégibb trachomaellenes intézkedések hazánkban foganatosítottattak, s hogy a trachoma ellenes védekezés nálunk már 1886-ban törvénycikk által biztosíttatott." - emelte ki beszámolójában Brana doktor [22]. Az egyetemi orvoskari bizottság megítélés szerint „a trachoma elleni küzdelmet is reformálni kívánja, amely eddig főként 


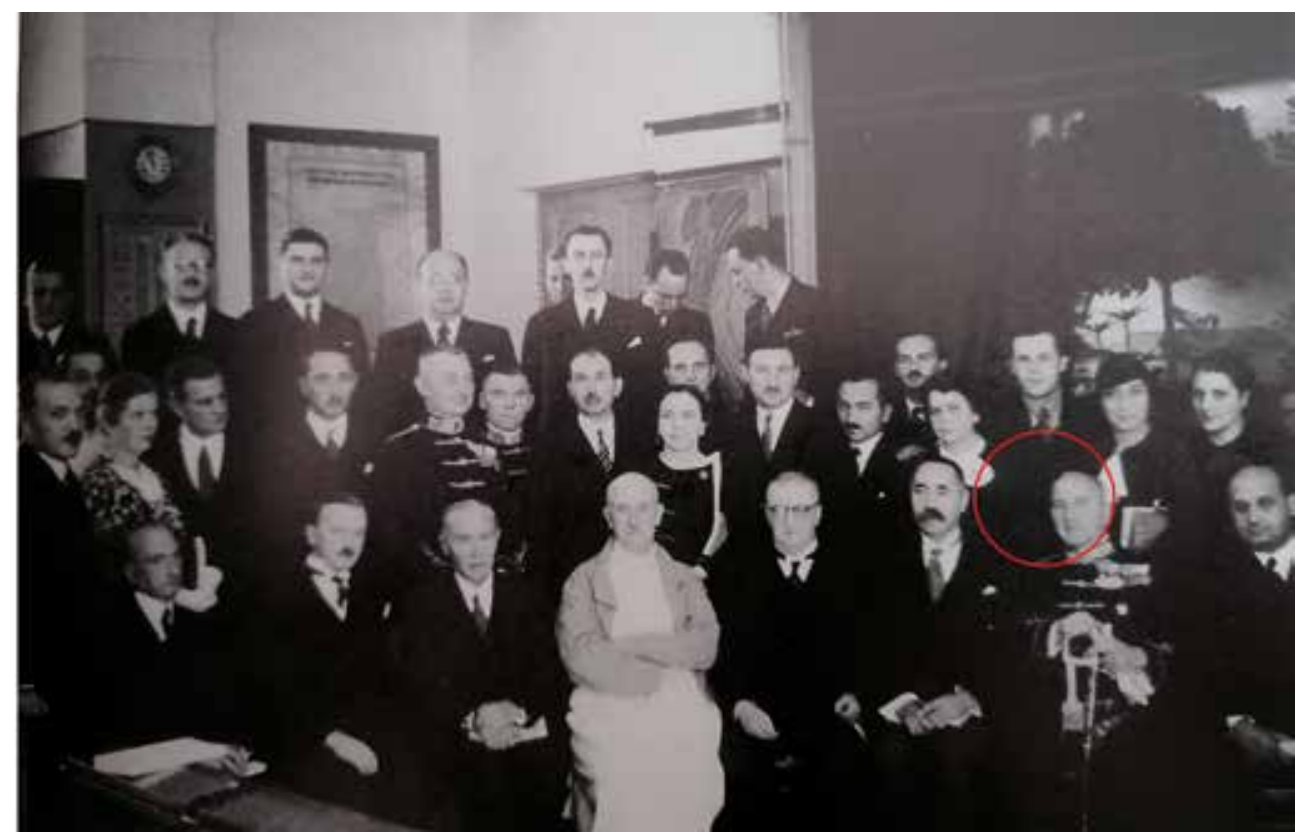

A Magyar Szemorvostársaság a Mária utcai Szemklinika egyik tantermében, 1935 [23]

a fertőzés meggátlására irányult, míg ő a hygienikus viszonyok megváltoztatására helyezné a hangsúlyt”. „De figyelembe kell vennünk - áll az ülés jegyzőkönyvében - a közellátóság keletkezéséről és a vérnyomásemelkedés összefüggéséről, a szemfenék elváltozásaira vallott nézeteit, vagyis összehasonlító vizsgálatainak eredményét is." A bizottság hangoztatta, hogy Brana János jelentős számú vizsgálati alany hossz távú megfigyelésével a szembetegségek és a belgyógyászati kórképek közötti összefüggéseket térképezett fel, így „a szemorvos a belgyógyásznak e tekintetben értékes útbaigazítást adhat. Amint ezekből látható, Brana gondos és buzgó vizsgáló, akinek dicséretére válik, hogy nagy kérdések megoldására törekedett. Ha ezekben nem is tudott meggyőző végleges eredményekre jutni, mégis el lehet ismernünk, hogy több értékes adat birtokába juttatott bennünket" [24].
Mindazonáltal Brana János azt is fontosnak tartotta, hogy ne csak az egyetemi katedrán tanítson, hanem élt az ismeretterjesztés akkori modern technikai eszközei kínálta lehetőségekkel, a hírlapokban publikált tudománynépszerüsítő, gyakorlati tanácsokat tartalmazó cikkei mellett rádióelőadásokat is tartott, például Rövidlátás, túllátás címmel 1933. március 29-én [25] és 1934. április 10-én hangzott el előadása A szem egészségéröl [26].

1929-es újraindulástól az 1936-os évfolyam végéig a Honvédorvos címü, egyetlen hazai katona-egészségügyi profilú szakfolyóirat szerkesztője volt. A szakfolyóirat a két világháború közötti időszakában a formálisan 1924-ben megalakított [27] Honvédorvosok Tudományos Egyesületének orgánuma volt, így magától értetődően fonódott egybe a lap és a szakmai szervezet élete. Dr. Brana szerkesztőként és előadóként, szá- 
mos egyesületi tudományos rendezvény levezető elnökeként is aktívan részt vett a HOTE munkájában, a Honvédorvosban számos rövid hírt, közérdekü közleményt, referátumot is jegyzett a felelös szerkesztővel, Franz Gézával együtt, de önálló szemészeti szakmai publikációkat is közzétett a folyóiratban. Emellett magától értetődően volt részese a civil szakmai rendezvényeknek, az 1935. évi Orvosi Nagyhét szemorvostársasági ülésén például a szemfenéki érelváltozások jelentőségéről tartott referáló előadást [28].

A katonaorvosi szakmai közéletből nyugállományba helyezése után kivonult, és nem véletlen, hogy a HOTE megbecsülése jeléül az 1937. november 4-én tartott XVII. választmányi ülésén a Honvédorvos felelős szerkesztője, Dr. Franz Géza javasolta, hogy „Brana János dr. vezértörzsorvosnak nyugállományba való helyezése alkalmával jegyzőkönyvi köszönetet szavazzunk a szerkesztésben való közremüködéséért", és ugyanekkor Dr. Rassay Rezső felvetette azt is, hogy a HOTE alapszabály 5 . \$b. pontja alapján Brana Jánost tiszteletbeli taggá válasszák [29].

Az 1930-as években azonban másik nagy jelentőségü és mind a mai napig hatását éreztető tudományos programban is szerepet vállalt. Még a Nagy Háború előtt Paul Myrdacz jeles katonaorvos megfogalmazta, a világháború "nagy, tudásban gazdag tanítómester" és a tudomány fejlődése számára „eredeti, kutatásban gazdag esemény; egy rendkívül érdekes tömegkísérlet" [30]. $\mathrm{Az}$ első pillanatra megdöbbentő és számos erkölcsi kérdést felvető kijelentés igaza azonban a világháború kitörése után hamar beigazolódott, hiszen az új haditechnika, az elhúzódó állóháború és a harci cselekmények hatalmas föld- rajzi területekre kiterjedt volta speciális elvárások elé állította a hadsereget, a hátországokat és nem utolsósorban a katona-egészségügyi rendszer minden elemét. Az I. Világháború alatt új feladatot kapott a közgyüjteményi rendszer is. A háborús vonatkozású könyvtári jellegü, leginkább nyomtatott vagy kéziratos forrásokból az OSZK-ban világháborús különgyüjtemény szerveződött. A katonai tárgyi eszközökböl és a Nagy Háború alatt készült katonai hivatalos és magániratokból, relikviákból pedig a Hadtörténeti Intézet jogelődje teremtődött meg még 1918-ban, a Hadtörténeti Könyvtár alapítása pedig 1920-ban történt meg [31]; a gyüjtemények 1929 nyarán nyerték el mai elhelyezésüket a volt Nádor-laktanyában [32]. A Hadi Múzeum ezután is több felhívással fordult az orvosokhoz: „A Magyar Királyi Hadi Múzeum könyvtára a világháborúra vonatkozó összes irodalmi termékeket gyüjti és ezekről szabályszerü katalógust vezet." A Hadi Múzeum igazgatósága felkérte az orvosokat, hogy világháborús orvosi témákkal foglalkozó tudományos közleményeiket és dolgozataikat küldjék meg a Könyvtár részére. A tanulmányok, írások, feljegyzések, naplók összegyüjtésével pedig Dr. Brana János I. osztályú fötörzsorvost, a Budapest I. kerületi Alkotás utcai (korábbi 17. számú helyőrségi) kórház igazgatóját, egyetemi magántanárt bízták meg. „Ugyancsak újból felkérjük az orvostársadalmat, klinikákat és egészségügyi intézeteket, hogy a birtokukban levő akár a világháborúból, akár a régi múltakból fennmaradt egészségügyi vonatkozású értékesebb emlékeket a hazafias cél érdekében letét vagy ajándék formájában a Hadi Múzeum egészségügyi szakosztálya részére átengedni szíveskedjenek. A beszállításra és -szolgáltatásra vonatkozó bárminő felvilágo- 
sítást szintén fentnevezett nyújt" [33] olvasható az MTI 1931. november 10-ei egyik híradásában.

A korabeli magyar orvostársadalom tudományos és közösségi életének érdekes színfoltja volt a vallási, egyházi kötődésen alapuló Magyar Katolikus Orvosok Szent Lukács Egyesülete, amely 1931. október 25-én tartotta alakuló ülését [34], a szervezetet 1937ben jegyezték be és 1947. január 17-én szüntették meg miniszteri rendelettel éppúgy, mint a Honvédorvosok Tudományos Egyesületét [35]. (Érdemes megjegyezni, hogy a rendszerváltoztatás után, 1991-ben úgy a Magyar Katolikus Orvosok Szent Lukács Egyesülete, mind a Katonaorvosi Társaság újjászerveződött, utóbbi ma Magyar Katonai Katasztrófaorvostani Társaság néven működik.) Nyugalmazott orvos tábornokként Brana János az 1930-as évek végén alelnöke volt az egyesületnek [36] és nem csak ennek volt köszönhető, hogy az 1938-ban Budapesten megrendezett XXXIV. Nemzetközi Eucharisztikus Kongresszus egészségügyi fönökének éppen őt kérte fel a rendezvény szervező bizottsága, hiszen ezekben az esztendőkben nagyon is tevékeny, ismert és elismert tudós orvos volt, aki katonai pályafutása során nem csupán klinikusként, hanem a Nagy Háborúban és hadifogsága idején az egészségügyi rendszer szervezőjeként, nagy embertömegek orvosi ellátásának biztosítójaként szintén bizonyított.

Koncepciójának megfelelően kongresszus teljes ideje alatt, 1938. május 24-étől 30-án estig közel 200 orvos, több száz ápolónő és mentő munkába állításával építette ki az egész országot behálózó szolgálatot. A Magyar Orvosok Szent Lukács Egyesülete, a Vöröskereszt, a Zöld- és a Kékkereszt ápolónői, a városi

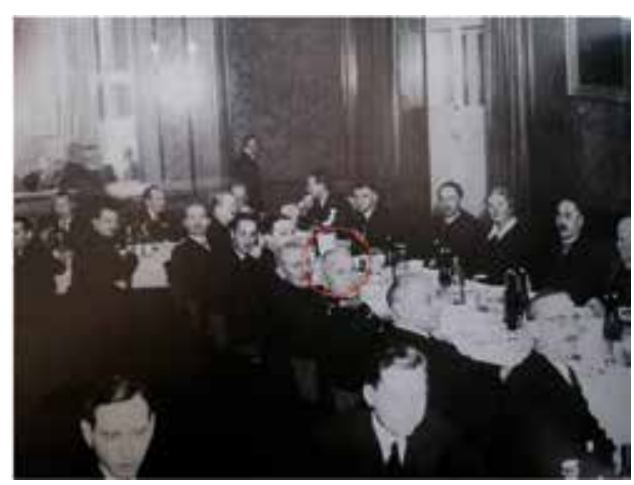

Dr. Grósz Emil 75. születésnapjának ünneplése a Gellért Szálló

különtermében, 1940. december 7.

és vármegyei mentőegyesületek, a nagy tömegeket vonzó események helyszínein föként a Budapesti Önkéntes Mentőegyesület segítségével szervezte meg az akkori Horthy Miklós Közkórházra (a mai Bajcsy-Zsillinszky Kórházra) és egyéb gyógyintézetekre, összesen 1200 férőhelyre alapozva zarándokok orvosi ellátását. A pályaudvarokon a Vöröskereszt helyi szervezetei adtak ügyeletet, Budapesten pedig külön pályaudvari egészségügyi kirendeltségek működtek, a tömegszállásokon önkéntes doktorok állandó egészségügyi szolgálata és gyengélkedőszobák álltak rendelkezésre. A rendezvény idejére a fóvárost 10 orvosi kerületre osztotta fel; az úton lévőkre 10 kilométerenként egy-egy segélyhelyet telepített elsősegélynyújtásra kiképzett személyzettel és „mentőszekrény”-nyel, minden $50 \mathrm{~km}$-re pedig a Városi és Vármegyei Mentőegyesületek mentőautói ügyeltek [37].

Az 1938-as esztendő az utolsó békeév is volt, így utóbb Brana János doktor személyes sorsa is a II. világháború eseményeihez kötődött. 1944-ig nyugalmazott orvos tábornokként és egyetemi tanárként Budapesten szolgálta hazáját a romló egészsége adta lehetö- 
ségeken belül. A háború alatti és utáni tevékenységéről nem sok forrás áll az utókor rendelkezésére, csupán néhány hírlap elszórt híre és Branának az Orvosi Karhoz megküldött igazoló jelentése ad némi felvilágosítást utolsó éveiről. A jelentést a Pázmány Péter Tudományegyetem orvoskarának 1947. január 14ei tanácsülésén tárgyalták.

Miután Brana János több éven keresztül szenvedte az orosz hadifogságot a Nagy Háború alatt és 1917-ben Pétervárott a Kerenszkij-féle forradalom tanúja lett, majd Zágrábban és Szegeden tartózkodva élte át az 1918-as és 1919-es balratolódásokat, a front, a Vörös Hadsereg közeledtével (és frissen mütött szeme miatti aggodalomtól is hajtva) Nyugat-Magyarországra menekült; a kőszegi katonai reáliskola orvosa lett. Amikor az iskolát sok egyéb intézménnyel együtt nyugatra telepítették, akkor ő még Magyarországon maradt és város betegeit gyógyította, 1945. március 28-án azonban parancsra több százezer magyarral együtt Németországba távozott [38]. A Világosság címü lap 1945. október 13-ai „hadifogoly- és deportáltszolgálata" szerint vitéz (Bogdánfy) Brana János akkor a németországi metteni gyüjtőtáborban (menekülttáborban) tartózkodott, és a tábor parancsnoka volt [39]. Szívpanaszai és gyomorfekélye miatt 1946. június 4-étől Bad Reichenhall kórházában kezelték, 1947 áprilisában haza szándékozott jönni, hazatérésig írásbeli igazoló jelentése elfogadását kérte egyetemi tanár kollégáitól: „Jelentem továbbá, hogy soha életemben sem politikával nem foglalkoztam, soha semmiféle politikai pártnak tagja nem voltam és soha senkinek sem szóval, sem tettel nem ártottam." [40]

Végül azonban már nem tudott, vagy a hazájából érkező kedvezőtlen hí- rek miatt nem akart Budapestre visszautazni. 1949 nyarán „az USÁ-ba szóló assurance-t, meghívást kapott elismert tudományos szakirodalmi munkásságának folytatására. Három nap múlva azonban váratlanul meghalt 68 éves korában". Az emigrációban felesége, mellette sógornője és sógora Demeter László huszárezredes osztozott sorsában [41].

Dr. Brana János orvos tábornok, kórházunk szemészeti osztályának munkatársa és utóbb vezetője volt, katonaorvos békében és háborúban, a XX. századi magyar történelem több fordulópontjának tanúja, kitaszított hadifogoly és ünnepelt egyetemi tanár, de a rábízottakért és az egész nemzetért mindenkor felelősnek érezte magát fogolytársként, parancsnokként egyetemi tanárként vagy közszereplőként.

\section{Irodalom}

[1] Forrás: A XXXIV. Nemzetközi Eucharisztikus Kongresszus emlékkönyve. Szent István Társulat, Budapest, 1938: 37.

[2] A budapesti Királyi Magyar Tudomány-egyetem almanachja az MDCCCC-MDCCCCI. tanévre. Magyar Királyi Tudomány-egyetemi Könyvnyomda, Budapest, 1901: 174.

[3] Schematismus für das k. u. k. Heer ... für 1914. K. k. Hof- und Staatsdruckerei, Wien, 1914: 1156.

[4] Brana J. anyakönyi lapja. HM Hadtörténeti Intézet és Múzeum Hadtörténelmi Levéltár [a továbbiakban: HL]. Felülvizsgálati iratok. Dr. Brana János. 71. doboz.

[5] Dr. Brana János örnagy. HL. HM Lymbus 1920/3.; Szegedről jelentik. Magyarország. 1915. április $14 .: 8$.

[6] Vö. Papp F.: Kaszinók az Osztrák-Magyar Monarchiában. Hadtörténelmi Közlemények. 2014.: 504-520. 
[7] Wissenschaftlicher Verein der Militärärzte der Garnison Przemysl. Sitzung am 1. Dezember 1913. Militärart. 1914.: col. 121.

[8] Brana J.: Orvosi megfigyelések és tapasztalatok orosz hadifogságban. Magyar Katonai Szemle. 1932, 12.: 179-190.

[9] Beszélik... Szeged és Vidéke. 1916. július 24.: 3.

[10] Budapesti czím- és lakásjegyzék. 1922-1923. Franklin-Társulat, Budapest 1923: 32. és uott. 1928: 237.

[11] Sági E.: A budai katonai kórház szervezési adatai és müködése 1950-ig. Orvosi Hetilap. 2000:1359-1360.

[12] Dr. Brana János örnagy. HL. HM Lymbus 1920/3.; Brana J. anyakönyvi lapja. HL. Felülvizsgálati iratok. Dr. Brana János. 71. doboz

[13] Brana J. anyakönyvi lapja. HL. Felülvizsgálati iratok. Dr. Brana János. 71. doboz.

[14] Baross E. (főszerk.): Magyarország közhivatalainak cím és adattára. 1942. Magyarország Közhivatalainak Cím- és Adattára Kiadóhivatala, Budapest, 1942: 170.

[15] Magyarország tiszti cím- és névtára. 1940. Athenaeum, Budapest, 1940: 570.: Uott. 1942. Athenaeum, Budapest, 1942: 717.

[16] Magyar Katonai Szemle. 1933. 1: 262.

[17] Honvédségi Közlöny. Személyes ügyek. 1942: 593.; Révai kétkötetes lexikona. 1. köt. Révai, Budapest, 1947: 213.; Nemzetvédelmi Kereszt adományozása. Nemzeti Újság. 1942. augusztus 14.: 6 .

[18] Saját felvétel, a család tulajdonában.

[19] A Budapesti Kir. Orvosegyesület jubiláris évkönyve. 1837-1937. Budapesti Királyi Orvosegyesület, Budapest, 1938: 13.

[20] Vö. A Budapesti Királyi Magyar Pázmány Péter Tudományegyetem Orvostudományi Karának ülései. 1937-38. p. 24-29. https:// library.hungaricana.hu/hu/view/SOTE_KARI_ORVOSTUD_1937-1938/?query=brana \&pg $=418$ \&layout $=\mathrm{s}$

[21] Brana J.: A trachoma elleni küzdelem Magyarországon. Honvédorvos. 1929: 17-20.
[22] Brana J.: Amsterdamban megtartott XIII. nemzetközi szemészeti kongresszus. Honvédorvos, 1929: 133-134.

[23] Bögi J.: Képek a 90 éves Mária utcai Szemklinika életéből. Semmelweis Orvostudományi Egyetem Képzéskutató, Oktatástechnológiai és Dokumentációs Központ, Budapest, 1999: 25.

[24] Vö. A Budapesti Királyi Magyar Pázmány Péter Tudományegyetem Orvostudományi Karának ülései. 1937-38. p. 24-29. https:// library.hungaricana.hu/hu/view/SOTE_KARI_ORVOSTUD_1937-1938/?query=brana \&pg $=418$ \&layout $=\mathrm{s}$

[25] Rádió. Szabolcsi Hírlap. 1933. március 29.: 4.; Eger. 1933. március 30.: 4.

[26] A budapesti rádió műsora 1934. április 8-tól április 14-ig. Délmagyarország. 1934, április 8.: 17 .

[27] Egyesületi ügyek. Honvédorvos, 1929: 15.

[28] Brana J.: A szemfenéki érelváltozások jelentősége. Honvédorvos. 1936: 55-63.

[29] Egyesületi ügyek. Honvédorvos. 1937: 206207.

[30] Rauchensteiner, M.: Az első világháború és a Habsburg Monarchia bukása. Zrínyi, Budapest, 2017: 183.

[31] Vö. Andaházi-Szeghy V.: A hadtörténeti Könyvtár története. Hadtörténelmi Közlemények, 2018: 142-173.

[32] Hadtörténeti Intézet és Múzeum. Történet. URL: www.militaria.hu/hadtortenetiintezet-es-muzeum/tortenet

[33] MTIhírek. 1931.november 10.6. kiadás. URL: https://library.hungaricana.hu/hu/view/ NapiHirek_1931_11_1/?query=brana $\% 20$ hadi $\% 20 \mathrm{~m} \%$ C $3 \%$ B A zeu m \& p g $=256$ \&layout $=\mathrm{s}$

[34] Nemzeti Újság. 1931. október 24.: 8.

[35] Magyar Katolikus Orvosok Szent Lukács Egyesülete. URL: https://archives.hungaricana.hu/hu/archontologia/55114/ 
[36] Magyar Országos Tudósító. 1938. május 27. https://library.hungaricana.hu/hu/view/ MOT_1938_05_2/?query=brana $\% 20$ szent $\% 20$ luk \% C $3 \%$ A 1 cs $\% 20$ egyes $\%$ C3\%BClet\&pg=196\&layout $=\mathrm{s}$

[37] Az Eucharisztikus Kongresszus egészségügyi szolgálata. Pesti Hírlap. 1938. március 3.: 4.; A Magyar Orvosok Szent Lukács Egyesületének eucharisztikus díszgyülése. Nemzeti Újság. 1938. június 3.: 10.; Az eucharisztikus kongresszus egészségügyi szolgálatáról. Tolna Megyei Újság. 1938. május 4.: 3.

[38] Pázmány Péter Tudományegyetem Orvostudományi Kar. Tanártestületi ülések. 1946/1947. 1947. január 14. https://library. hungaricana.hu/hu/view/SOTE_KARI_ ORVOSTUD_1946-1947/?query=brana\&pg $=470 \&$ layout $=\mathrm{s}$

[39] A Világosság hadifogoly és deportáltszolgálata. Világosság. 1945. október 13.: 4.

[40] Pázmány Péter Tudományegyetem Orvostudományi Kar. Tanártestületi ülések. 1946/1947. 1947. január 14. https://library. hungaricana.hu/hu/view/SOTE_KARI_ ORVOSTUD_1946-1947/?query=brana\&pg $=470 \&$ layout $=\mathrm{s}$

[41] Tragikus sors. Hungária : Hontalan magyarok hetilapja. 1949. július 8.: 8 .

\section{Gabriella Pogány Rózsa PhD}

\section{János Brana MD (1881-1949) major general, ophthalmologist, professor Changes of history and important events in the life of a Hungarian military doctor}

János Brana MD (1881-1949) from Transylvania was an ophthalmologist, a military doctor and professor of the Medical faculty of the Hungarian Royal Pázmány Péter University in Budapest. His life represents the changes of the Hungarian history of the 20. century. First he was a military doctor of the Imperial and Royal Army of the Austro-Hungarian Monarchy, after the fall of the Monarchy he served in the Hungarian Royal Army. In his scientific work between 1929 and 1936 he was the editor of the military medical journal Honvédorvos and member of the Scientific Association of the Doctors of the Hungarian Royal Army and a well-known agent of the public life of doctors of the first part of the 20 . century.

Key-words: János Brana MD, biography, Honvédorvos 1929-1936, history of military medicine

Pogányné Rózsa Gabriella PhD 1134 Budapest, Róbert Károly krt. 44. 